\title{
The Effect of Make a Match Strategy on Students' Reading Comprehension of Descriptive Text
}

\author{
Irma Khairunnisa ${ }^{1}$, Ratna Sari Dewi ${ }^{2}$, Zaharil Anasy ${ }^{3}$ \\ \{Khairunnisairma04@gmail.com ${ }^{1}$, Ratna@uinjkt.ac.id ${ }^{2}$, Zaharil.anasy@uinjkt.ac.id ${ }^{3}$ \} \\ ${ }^{1,2,3}$ UIN Syarif Hidayatullah Jakarta, Indonesia
}

\begin{abstract}
This study aimed to find the empirical evidence of the Effect of Make a Match Strategy on Students' Reading Comprehension of Descriptive Text at the Seventh-Grade of MTs Negeri 4 Jakarta in Academic Year 2018/2019. The population of this study was the seventh-grade of MTs Negeri 4 Jakarta. The sample was 60 students selected by purposive sampling technique and was divided into two classes; experimental class and controlled class. The method used in the study was a quantitative method using a quasiexperimental design. The research instruments of this study were 25 multiple choice questions and 5 matching words. The data were analyzed using the t-test. The result of the data showed the diversities of experimental and controller class post-test scores in reading comprehension of descriptive text. The post-test score of the experimental class was increased than the pre-test score after applying the strategy on students' reading comprehension. Also, the effect size result was 0.9. It proved that Make a Match strategy was effective to use at a moderate level on students' reading comprehension of descriptive text at the seventh-grade of MTs Negeri 4 Jakarta in the academic year 2018/2019. Thus, to use this strategy in teaching reading comprehension of descriptive text, the teacher cannot teach the theory of descriptive text specifically because the activity needs more practice in the classroom.
\end{abstract}

Keywords: Reading Comprehension, Make a Match Strategy, Descriptive Text

\section{Introduction}

Reading comprehension is one of the English language skills that should be mastered by English Foreign Language Learners (EFL). 2013 curriculum stated that students need to improve their reading comprehension to get knowledge from their English learning sources. Reading comprehension as a process to understand the writer's idea in a written text to get essential information from it as efficiently as possible [1]. Although students must master reading comprehension, these skills are considered as a complex activity for students. It is because students need a useful combination of processing skills. The skills used in reading comprehension are the speed movement of the eyes and mind to absorb the intent of the text simultaneously [2].

Furthermore, students need to learn several kinds of functional text besides learning reading comprehension, the curriculum also states that students need to learn about the descriptive text. A descriptive text is aimed for a lot of purposes. First, the text provides an impression about a place, person or thing to the readers. Second, it allows the reader to imagine an abstract idea and makes essential information about the object described. The last, descriptive text can be used to promote an argument that requires description [3]. 
However, along with teaching and learning process, students faced several problems in reading comprehension of descriptive text. Then, the teacher should overcome the problems by finding an appropriate approach, technique or strategy in teaching reading to the students.

Based on the observation, students of MTs Negeri 4 Jakarta often considered reading comprehension of the descriptive text as boring activity in the classroom. It is because the students have a lack of vocabulary and a monotone technique used by the teacher.

The previous researches mostly focus on the students' performance of reading comprehension without used specific kinds of text. In this research, the focus will be on the effect of Make a Match Strategy on students' reading comprehension of Descriptive Text at Seventh-grade students of MTs Negeri 4 Jakarta. The researcher chose the class based on her observation and interview with the English teacher. It was found that seventh-grade students still at the beginner level of English language skills.

\section{Literature review}

\subsection{Reading Comprehension}

Reading comprehension is considered as an important skill for EFL learners. Because of reading, they can get the knowledge from their English learning sources. Reading comprehension also can be defined as a process to understand the writer's idea in a written text to get essential information from it as efficiently as possible [4]. Readers must know the meaning of the text, decoding the text, and recognize the syntactic order of the sentence. Through this process, the readers will interpret, integrate and connect their past experiences with the text. Therefore, the readers interact dynamically with the text as they try to obtain the meaning of the text [5].

Reading comprehension is a complex activity for students because it needs a useful combination of processing skills. The skills used in reading comprehension are the speed movement of the eyes and mind to absorb the intent of the text simultaneously [6]. In a nutshell, reading comprehension is a process of reading that requires some abilities to absorb the information needed from the text.

Kinds of Reading. Two types of reading, namely Intensive Reading and Extensive Reading. Intensive reading allows the readers to understand how the meaning arranged, instead of the meaning of the text only. In this kind of reading, the teacher's guidance encourages students to focus on the text, so it makes Intensive Reading is suitable to do in the classroom. Intensive Reading can escalate the reading comprehension of the readers. This type of reading is effective in improving reading comprehension because it needs the students to combine some strategies, such as metacognitive, schematic and linguistic [7].

The second type of reading comprehension is Extensive Reading. Like the name, Extensive Reading means the reader has to extend the interpretation of the text. Extensive reading requires the reader to be familiar with the construction of every section of the text: sentences, paragraphs, and chapters of the whole book. In Extensive Reading, the reader needs to make meaning of the text rather than know the content. Extensive reading is a superior tool to enlarge the target language input for students. It could happen when the reader more comfortable to do self-selected text based on their desired text [8].

Purpose of Reading. Primary purpose of reading is to get information from the text. Thus, after getting the data, usually, the reader stops reading. Additionally, Anderson in Nunan's book revealed the two purposes of reading. The first is reading for pleasure. The words that appeared in the books are a universal language or understandable for foreign learners. For that 
reason, it makes the books more attracted learners of all ages to read. Engrossed in reading stories, students unwittingly learned their target language from the books quickly. It is known as reading for pleasure.

The second purpose of reading is reading for information. Aside to entertain themselves, the readers are reading a book to find their needed information. Anderson gave an example of a child who interested in dinosaurs may like to read a book about a prehistoric animal. In this case, reading for information also can give the readers enjoyment in reading [9].

\subsection{The Concept of Descriptive Text}

Descriptive text is outlined as a text which describes a particular animal, people or things to the readers in specific ways. The particular information which can be described with a descriptive text is: the aroma, feels, sounds, appearance and the sense of the object [10]. Besides, descriptive text not only tells about a particular object but also a favorite object which the writer adores such as someone's personality, character, and feeling [11].

The Generic Structure of Descriptive Text. The descriptive text consists of the identification which appears at the beginning of the paragraph to introduce the object. On the other hand, the description part describes the character or the qualities of the objects [12]. The identification becomes the first part of introducing briefly the object to describe. This part usually mentions the name and essential explanations about the object. It starts with an introductory paragraph of the text then continues with several explanations paragraphs. The second generic structure of the text is description. The description part tells about each section or feature of the object described. It begins with the explanation of the general physician to the unique specification quality and the habit of the human, animal or thing explained.

Language Features of Descriptive Text. Besides the generic structure, the descriptive text also has several linguistic features. First, it focuses on what is the prominent or distinctive part of the object that the writer wants to describe. Second, the descriptive text uses the present tense. Because the descriptive text focuses on describing a real object, it requires to use the simple present tense. Third, Linking verbs in the descriptive text are used to describe the appearance of an object or function of the parts contained in the object represented, for example; am, is, have, etc. Next, the use of action verbs are also one of the language features in the description text. Each text that is studied academically has the language features criteria used, as well as descriptive text. Fifth, Mental verbs in the descriptive text are used to describe feelings in the text. One of the aims of descriptive text is to express feelings or sense. And the last is adjectives used in the descriptive text to provide more detail information for objects that are being described [13].

\subsection{Make a Match Strategy}

Lorna Currant developed Make a Match strategy in 1994. This strategy is a part of Cooperative Learning. Cooperative learning is used for a long time in education. The propriety of the learning style is students' collaboration in groups during the learning process. One of the characteristics of cooperative learning is compactness among students. The students are required to be active and creative during the learning situation [14]. Besides, the teacher ought to prepare and give the students material during the lesson and sometimes give them a case. Furthermore, the students need to solve the problem with their groups. 
This strategy needs a teacher and students' teamwork. Before the activity begins, students ask to read a descriptive text, while the teacher prepares the cards (question and answer cards). After that, the students are divided into two groups; A and B. Each student of the groups takes one card. The student in group A receives an answer card, and group B gets a description card. Next, the teacher gives several minutes for students to find their match. In the last step of the strategy, students must provide the teacher with a report after they find their match. And then, the teacher asks them to explain their results in front of the class.

Advantages and Disadvantages Using Make a Match. Make a Match strategy is suitable to increase the students' interest in reading the descriptive text. The strategy also allowed students to directly hook with the material. Some advantages noticed on the use of Make a Match: First, students feel more interested in reading comprehension of descriptive text because they can interact and move with their friends to find the matching cards. Second, because the students have to read the detail information of the text, it will increase their focus to the descriptive text. Third, the strategy will expand their attention of unfamiliar words. It is happen when the teacher has asked the students to comprehend the text, the students may find difficult words and they might be curious with the meaning of the words. Because of their curiousity about the meaning of unfamiliar words, the the words can stay longer in the students' mind than the words that they remember regularly. Agus Suprijono added, in learning process using Make a Match strategy, teacher as a facilitator should give the students chance to confirm their matches [15].

Besides those advantages, Make a Match also has some disadvantages; Firstly, it takes a long time because the students would spend most of their time to move. Secondly, because it uses cards as the media of learning, the teacher needs an extra effort to provide adequate media of learning. Third, in using this strategy, teacher cannot specifically focus to teach theoretical of descriptive text because the activity needs more practices in the classroom. The last is the teacher is required to be active in controlling the class.

\subsection{Conceptual Framework}

Reading comprehension is one of an English skill that should be learned for the students. It needs the combination of a complex skill; therefore, reading comprehension is often to be a problem for seventh grades students. Besides, the students have a lack of motivation to develop their skills. Thus, the teacher should find a strategy suitable for the students to improve their reading comprehension. One of the solutions that can be applied in the class is Make a Match Strategy.

The researcher assumed that Make a Match strategy can increase students ' focus and interest on reading comprehension of descriptive text. Because they have to move and interact with their partner, Make a Match strategy will give students an exciting classroom atmosphere during the learning process.

In addition, the strategy will make the students aware of unfamiliar words, so it challenges them to know the meaning and memorize it. Before using the strategy, the teacher gives students time to read the text which given. After that, the teacher gives the students opportunity to ask the difficult words and discuss about the text. From those activities, the vocabularies can stay longer in their mind than when they memorized them reguraly.

It can be synthezised that the researcher chose Make a Match strategy to help students in resolving their problem in reading comprehension of descriptive text. Therefore, Based on the explanation above, it can be posed; 
Null hypothesis (Ho): There is no effect of using Make a Match strategy in students' reading comprehension of descriptive text.

Alternative Hypothesis (Ha): There is a significant effect of using Make a Match strategy in students' reading comprehension of descriptive text.

\section{Methodology}

This research used a quantitative research method with Quasi-Experimental Design. This paper used a reading test as the instrument. The students were asked to answer an appropriate choice The test consists of 25 multiple choice questions and five matching words taken from National Exam questions, Final Exam questions of seventh grade students and several books containing descriptive text. Before applying to Make a Match Strategy, a pre-test was given to the samples and the post-test was given after the treatment in an experimental class by using Make a Match Strategy.

The population of this study was seventh grades students of MTs Negeri 04 Jakarta academic years of 2018/2019. It consists of 248 students divided into eighth classes. Furthermore, two classes will be samples of this research. 7.3 class took the role as the experimental class and 7.4 class took the role as the controlled class. The classes were chosen based on pre-test scores and teacher recommendation.

\section{Data Analysis and Result}

The normality test is conducted to assess whether the data had been normally distributed or not. The significance (Sig.) score in the Kolmogorov-Smirnov columns of both classes is $\geq$ 0.05. The experimental class is 0.032 and 0.101 controller class. By the result, it can be concluded that the data of the pre-test experimental class and controller class are in the normal distribution. Then, the homogeneity test is conducted to find out whether the data from the experimental class and controlled class is homogeneous. The data results that the Sign. value from the post-test score was 0.086 . Since the data is higher than the significance level $(0.086$ $\geq 0.05$ ), it can be concluded that the data of the post-test is homogeneous. Finally, to discover the effect of Make a Match strategy on students reading comprehension of descriptive text at MTs Negeri 04 Jakarta the hypothesis test is carried out. Thus, the test of effect size has a contribution to support the T-test result. The test takes the data from the post-test score of experimental and controller classes to be compared which shows that standard deviation in the experimental class is descreasing, from 11.525 to 7.736 . in addition, the pre-test and post-test score of both classes are significantly increasing. In other words, the teaching reading comprehension through Make a Match Strategy is successfully applied in the class and all students showed their progress together. The result of independent samples shows $p$-value or sig (2-tailed) of the research at 0.001. Because the $p$-value $(0.001)$ is lower than sig a $(0.001<$ $0.05)$, it implies that the null hypothesis $\left(\mathrm{H}_{\mathrm{o}}\right)$ is rejected and the alternative hypothesis $\left(\mathrm{H}_{\mathrm{a}}\right)$ is accepted. Accordingly, there is a statistical significance of using Make a Match strategy on students reading comprehension of descriptive text at seventh-grade students' of MTs Negeri 4 Jakarta.

Effect size test is the last step after the t-test in order to decide the level significance of the effect using Make a Match strategy on students' reading comprehension of descriptive text. The calculation presents that the effect size of this research is at the valoue of 0.95 that is categorized as a moderate effect. In other words, Make a Match strategy has a sufficient effect on students' reading comprehension of descriptive text. 


\section{Discussion and Recommendation}

\subsection{Discussion}

After all the tests, the result of this study showed that Make a Match strategy is effective on students reading comprehension of descriptive text at seventh grades of MTs Negeri 4 Jakarta. Based on the statement, the results of the research have answered the research question stated in chapter one in this study.

Indeed, the result of this study supported the previous related studies which assumed and proved that Make a Match strategy is effective on students reading comprehension of descriptive text. It also showed that teaching reading comprehension of descriptive text using Make a Match strategy made the learning process became actively and enjoyable.

Furthermore, the description of the data showed the increasing mean score from the experimental class after implemented Make a Match strategy from 60.07 became 76.73. Meanwhile, the score of the controller class also slightly improved although they did not apply the strategy. It is 64.13 became 67.36 .

Besides, the researchers found that the independent t-test indicated that Make a Match strategy is a statistically effective. This can be seen from the analysis of post-test data that the $\mathrm{p}$-value or $\operatorname{sig}(2$-tailed $)=0.001<\operatorname{sig} \mathrm{a}=0.05$. From the results, it concluded that the alternative hypothesis (Ha) is accepted and the null hypothesis (Ho) is rejected.

Accordingly, Make a Match strategy is effective on students reading comprehension of descriptive text. Furthermore, the result of the effect size test is 0.95 . Based on the criteria of Cohens' $d$ effect size, 0.95 categorized as a moderate effect. In other words, Make a Match strategy has a sufficient effect on students' reading comprehension of descriptive text.

In conclusion, the result of the research established that Make a Match strategy is effective on students' reading comprehension of descriptive text for seventh-grade students of MTs Negeri 4 Jakarta in the academic year of 2018/2019.

\subsection{Recommendation}

The teacher needs to choose a suitable strategy to teach students with different learning types. The researcher suggests applying the Make a Match strategy in teaching reading comprehension of descriptive text since it had been proved effective in the class. Moreover, the teacher should teach the theory of descriptive text before apply the Make a Match strategy in teaching reading comprehension of descriptive text.

For students, Make a Match strategy can be the solution that can make them more focus, interested and comprehend in reading the descriptive text.

The other researchers who are interested in making a similar study, this research can be a reference. Besides, the researcher hopes that other researchers can explore more with different skills and design of studies.

\subsection{Conclusion}

This research was expected to prove the effect of Make a Match strategy on students' reading comprehension of descriptive text for seventh-grade students of MTs Negeri 4 Jakarta in the academic year 2018/2019. The researcher used two classes to do the research: experimental class and control class. The pre-test and post-test were conducted for both classes. The experimental class was taught by using Make a Match strategy while the 
controller class was not given the strategy. It is found that Make a Match strategy can make the post-test score of both classes higher than the pre-test score. On the other hand, to use this strategy in teaching reading comprehension of descriptive text, the teacher cannot teach the theory of descriptive text specifically because the activity needs more practice in the classroom. Moreover, the result of the effect size test taken from Cohen's $d$ is 0.95 . It indicated that the range effect of this research is at a moderate level. Because of the effect of the research only on a moderate level, it can be concluded that the strategy cannot give significant improvement on the students' score. Besides, the result of standard deviation from the pre-test of both classes is smaller than the post-test; 11.525 and 12.675 became 7.73676 and 11.82482 . It means that Make a match strategy is successfully applied in the class and all students showed their progress together. Therefore, the alternative hypothesis $(\mathrm{Ha})$ is accepted, and the null hypothesis (Ho) is rejected. The research proved that Make a Match strategy is effective on students' reading comprehension of descriptive text for seventh-grade students of MTs Negeri 4 Jakarta in the academic year 2018/2019.

\section{References}

[1] Komang Wastawan, S. C.: Increasing Students' Reading Comprehension Through Make a Match Method of Cooperative Learning at the First Grade of SMA. U-jet. Vol 3 (2), pp. 1-11 (2010)

[2] Husna, N.: Step by Step to Reading Skills. Jakarta: English Education Department of Syarif Hidayatullah State Islamic University Jakarta (2010)

[3] Zainuddin. The Effect of Cooperative Integrated Reading and Composition Technique on Students Reading Descriptive Text Achievement. Eric Journal. Vol 8 (5), pp. 11 (2015)

[4] Komang Wastawan, S. C.: Increasing Students ${ }^{e e}$ Reading Comprehension Through Make a Match Method of Cooperative Learning at the First Grade of SMA. U-jet. Vol 3 (2), pp. 1-11 (2010)

[5] Sofyan A. Gani, Y. Q.: Progressive outcomes of collaborative strategic reading to EFL learners. Banda Aceh: Kasetsart Journal of Social Sciences (2016)

[6] Husna, N.: Step by Step to Reading Skills. Jakarta: English Education Department of Syarif Hidayatullah State Islamic University Jakarta (2010)

[7] Weidong Yang, W. D.: Intensive Reading and Necessity to Integrate Learning Strategies Instruction. English Language and Literature Studies. Vol. 2 (2012)

[8] Yulia, M. F.: Extensive Reading for Indonesian University Students: An Alternative Framework for Implementation. LLT Journal. Vol. 21 (2), pp. 208. (2018)

[9] Nunan, D.: Practical English Language Learning: Young Learners. New York: McGraw-Hills Companies (2005)

[10] Hogue, A. O. (Pearson Longman): Introduction of Academic Writing 3rd Edition. New York: Pearson Longman.

[11] Zainuddin: The Effect of Cooperative Integrated Reading and Composition Technique on Students ${ }^{e e}$ Reading Descriptive Text Achievement. Eric Journal. Vol. 8 (5), pp. 11 (2015)

[12] Zaida, N.: Mandiri Practice Your English Competence. Jakarta: PT. Gelora Aksara Pratama (2016)

[13] Anggun, S. K.: An Analysis of Descriptive Text in English Textbook using Transitivity System (A Case Study of Reading Passages). Journal of English and Education. Vol. 4 (1), pp. 147-158 (2016)

[14] Sulaiman: Model Pembelajaran Cooperative Learning (Suatu Analisis Psikologi dalam 
Pembelajaran). Vol. 5 (2), pp 27 (2014)

[15] Suprijono, A.: Cooperative Learning: Teori dan Aplikasi PAIKEM. Yogyakarta: PT. Pustaka Pelajar (2014) 